\title{
The Igbo and Educational Development in Nigeria, 1846 -2015
}

\author{
S.I. Okoro, Ph.D \\ Department of History and International Relations, Ebonyi State University, Abakaliki
}

"Corresponding Author: S.I. Okoro, Ph.D, Department of History and International Relations, Ebonyi State University, Abakaliki

\begin{abstract}
The Igbo inhabit what is presently referred to as South East Geopolitical zone in Nigeria. They also make up a sizeable chunk of the population of another geopolitical zone-South South. These areas were located in the colonial-inspired Oil Rivers Protectorate and the Colony and Protectorate of Southern Nigeria. Between 1906 and 1914, a Protectorate of Southern and Northern Nigeria stood side by side each other as the main administrative divisions of the colonial state. At the behest of the British Colonialists, a Western type and missionary-inspired educational system was introduced and accepted by the dominant ethnicities of Igbo and Yoruba of the Protectorate of Southern Nigeria; while the Hausa/Fulani Muslim dominated Protectorate of Northern Nigeria rejected this education. This paper aims to analyze the development of the Western type educational system in the South East geopolitical zone (Igbo Area) of the country over the years since its implantation. It also seeks to determine what strides and challenges that have attended this development, and how the compatriots of the Igbo have viewed and reacted to this trend. The paper relies mainly on documented secondary sources and the publications and findings of such educational regulatory agencies as the National Universities Commission (NUC) and the Joint Admissions and Matriculation Board (JAMB), among others, to reach its conclusions.
\end{abstract}

Keywords: The Igbo, Western Education, Development, Nigeria

\section{INTRODUCTION}

New International Webster's Comprehensive Dictionary of the English Language conceives of education as "the systematic development and cultivation of the natural powers by inculcation"1. As an intellectual process, it involves the handing down or transmission or transfer of ideas and values from one generation to another. ${ }^{2}$ Education is further seen as the aggregate of all the processes by which a child or young adult develops the abilities, attitudes and other forms of behaviour which are of positive value to the society in which the lives. ${ }^{3}$ It is thus a process for transmitting culture in terms of continuity and growth, and for disseminating knowledge either to ensure social control or guarantee rational direction of society or both. Seen in these prisms, education remains a veritable means of training the mind of an individual to enable him or her to acquire those skills and norms necessary for material, spiritual and cultural survival in his/her community or environment. ${ }^{4}$

From the foregoing, it is trite that education is a deliberate and conscious predilection and disposition; in fact a duty that society owes its young ones or offspring. Every society thus strives to evolve ways and means of inculcating the skills, ideas and values in its offspring so as to enable them function effectively both for their own benefits and that of the society. These conscious and deliberate inculcations, which invariably form part of the culture of the various communities and ethnic groups in what later became Nigeria, constituted traditional forms of education or what one may refer to as indigenous forms of education. Apart from the indigenous education mentioned above, two other educational traditions have flourished in Nigeria: Islamic/Koranic and Western type education. In this paper, we are concerned with the development of the Western type educational system among the Igbo of south - eastern Nigeria. Our intension is to determine what impact this educational system has had on the developmental trajectory of the people and society, and how the compatriots of the Igbo have received or reacted to this development and scenario over the years.

\section{WeSTERn Education In Igboland: The EARLy PhaSe}

In considering the evolution of western type educational system, Igboland must be seen as an integral part of what was referred to as Eastern Nigeria, which as indicated earlier, formed part of the Colony 
and Protectorate of Southern Nigeria. Eastern Nigeria included the lands east of the Niger River, north of the Gulf of Biafra, and west of the Cameroons. Between 1900 and 1939, this area, along with western Nigeria, was governed as a single unit called Southern Nigeria.

Between 1939 and 1967 it formed what was called Eastern Region of Nigeria. The Igbo, who formed seventy percent of the population ${ }^{6}$ of the Eastern region lived in the hinterland and the forest regions, away from the coastal regions or the Delta. Along the coast on the West, we had the Ijo/Ijaw, five percent of the population, on the eastern frontier, were the Ibibio/Efik, about eleven percent.

Inland in the north east, we had Cross River peoples, including the Ekoi that had affinities with the peoples of southern British Cameroons. ${ }^{7}$ This area was administered as part of Southern Nigeria during the Mandate period, and as part of the Eastern Region during the Trusteeship period. All the non-Igbo peoples mentioned above are not included in this study, even though they may have shared one experience or the other on the educational and administrative frontier.

The advent of Western education in what was to become Nigeria which Igboland became a part is usually intimately intertwined with the Christian missionary enterprise. This enterprise arose during and after the Dark Ages, and following the fall of the Roman Empire in the fifth century. During this period, according to A.B Fafunwa, the old literary and rhetorical education of the Roman era was almost completely destroyed because it was considered pagan in spirit. ${ }^{8}$ People became not only disenchanted but dispirited in either receiving or reviving it. This culminated into some kind of indifference to education generally by the church. The church however, soon realized that it could not do its work effectively unless its adherents were able to read and write. Realizing also the advantage of an 'education' that was tailored to its needs, it began to establish schools which were religiously biased, rather than the secular schools of the Roman era. In this scenario, educational authority was ultimately transferred from the state to the church. Having subsequently enacted a monopoly on education that lasted for more than a thousand years, the church proceeded to impart a tremendous impact on the intellectual life of Europe and America, which later on extended to British colonial territories in Africa and Asia. This was the background to the Christian missionary enterprise referred to earlier in Africa, including what later became Nigeria, to which our area of study belongs. It came in two phases: what Fufunwa refers to as first and second missionary endeavour. ${ }^{9}$

\section{THE FIRST MisSIONARY ENDEA VOUR}

This saw the arrival of the first Europeans: The Portuguese in what was to become Nigeria in the fifteenth century. In the later part of that century they reached the Gulf of Guinea, sailing the coast of the Mahin River in the mid-west to the forcados River and beyond. Being mostly merchants, the Portuguese nevertheless realized that if Africans were to be good customers, they will have to have some rudiments of education, and accept Christianity-the two 'civilizing' agencies in the estimation of the Europeans.

As early as 1472 Portuguese merchants had visited Lagos and Benin, having some exchanges with the Oba of Benin. It is reported that in 1485, a Portuguese merchant had some trade dealings in pepper with Binis, and a Bini citizen was sent as an emissary by the Oba of Benin to the Portuguese court in Lisborn. By 1515, some Portuguese missionaries had set up a school in the Oba's Palace. This was for the training of the sons of the Oba and his Chiefs who had been converted to Christianity. Between 1515 and 1552, the Portuguese merchants established some trading posts along the Benin River and around Lagos. ${ }^{10}$ It is to be noted that Lagos subsequently became an important Portuguese trading station, becoming extremely useful to the Portuguese in their obnoxious trade in slaves. The Portuguese contact later extended to the Delta areas of Brass and Warri, where they established trading posts, churches and schools.

As missionaries, the Catholics were the first to arrive Nigeria. Under the influence of the Portuguese traders, they established a seminary on the Island of Sao-Tome, off the coast of Nigeria in 1571. This was intended to train Africans as priests and teachers. From Sao-Tome, they visited Warri to establish schools and preach the Gospel. The early Catholic effort at missionary work in Nigeria suffered a devastating failure due to the ravages of the slave trade.

From this period to the early $19^{\text {th }}$ century, Africa remained virtually foreclosed to any sort of learning of the Western mould. With the abolition of the slave trade in 1807 at the behest of Britain, missionaries from various European powers began to penetrate the interior as explorers and 
evangelists. This penetration marked the so-called second missionary endeavour, within which our area of study featured.

\section{The SeCond Missionary Endeavour And EduCATIONAl DeVELOPMENT In IGbo LAND}

The second missionary endeavour in Nigeria saw the advent of the first English-speaking Christian mission in Badagry in 1842. Before this time, some of the liberated slaves that had been resettled in Freetown, Sierria Leone had travelled to Lagos and Badagry for commercial purposes, and in the process met with their children, parents and other relatives. They also brought messages back to Freetown from the relatives of those who did not travel. It was within this context that T.F. Buxton, a member of the anti-slavery movement in London began to advocate the exploration and cultivation of the area around the Niger waterway. This, according to him, was to turn the minds of the Africans from slavery to agriculture. He further suggested that missionaries and teachers will then take " the plough and hoe into the land and make agriculture flourish". ${ }^{11}$ Evangelism was thus to mix with business and commerce. It was envisaged that a time will come when the agents of commerce and Christian teachers, missionaries, artisans and others would encourage the cultivation of crops which would be shipped to Europe and then back to the African areas for sale as finished products.

These ideas, which were contained in Buxton's book ${ }^{12}$ were subsequently adopted by the British government, and they formed the basis for the famous Niger Expedition of 1841. This expedition marked one huge significant step by the British government in its effort to penetrate the hinterland of Nigeria. The expedition consisted of various specialists to study aspects of Nigerian life: political, social, economic and cultural aspects. It also included missionaries who were to explore the possibilities of missionary work in the Nigerian field, amongst others. Consisting of one hundred and forty four Europeans, and one African that happened to be a Nigerian, Samuel Ajayi Crowther, forty eight died of malaria and other illnesses. But the Nigerian was among the survivors!

Despite the failure of the Niger Expedition, it saw to the establishment of a model farm in Lokoja, the signing of treaties with local chiefs and most importantly for our present enterprise, the excitement of missionaries of diverse shades and persuasion to come to this part of Africa. It must be recalled that well before this expedition, some leading Yoruba settlers in Freetown, Sierra Leone had requested among other things, that missionaries be sent out to Badagry to preach the Gospel. In 1841, these emigrants also sent letters to missionaries in Sierra Leone urging them to come to Badagry. It is reported that the Revered Thomas Dore of the Methodist Mission expressed the wishes of the emigrants for their homeland in these words. ...

that the Gospel of God our Saviour may be preached unto her, that schools may be established, that Bibles may be sent, that the British flag may be hoisted, and she may rank among the civilized nations of the earth. ${ }^{13}$

The idea to evangelize Nigeria is noted to have originated from the Church Missionary Society (C.M.S) both in London and in Freetown, but it was the Methodists that first sent missionaries to Badagry.

The Reverend Thomas Birch Freeman, an offspring of a 'negro' father and an English mother, arrived Badagry on 24 September 1842, accompanied by one of the earliest educated Ghanaians, William de Graft. Beginning work in earnest, Freeman built a mission house and started prayer- meetings with the emigrants. Henry Townsend of the C.M.S, and two Egba ex- slaves from Sierra Leone - Andrew Wilholm and John McCormack later arrived to explore the possibility of establishing a mission in the area; to serve the spiritual needs of the C.MS emigrants from Sierra Leone. Townsend and his group later arrived Abeokuta on 4 January 1843. The party later returned to Sierra Leone, leaving Andrew Wilhelm to take charge of the Abeokuta Mission, just as Freeman also returned to the Gold Coast and left de Graft. The first known school was established by Mr \& Mrs. De Graft in Badagry, named 'Nursery of the Infant Church'.

As the Methodists and C.M.S. evangelists were consolidating their missionary activities in and around Badagry and Abeokuta, the Church of Scotland Mission sent an exploratory mission to Calabar in 1846. The group was led by the Reverend Hope Master ton Waddell, and comprised Mr. and Mrs. Samuel Edgerley, Andrew Chisholm and Edward Miller. The Roman Catholics were not to be left out in what may be described as spiritual scramble for Nigeria. Like their non-Catholic counterparts, the Brazilian ex-slaves who had settled in Lagos wanted to see Catholic mission schools established in 
Lagos. In 1868 , that wish was satisfied. As the $19^{\text {th }}$ century was drawing to a close, the big missions then, and even now, were well established in parts of Nigeria - the CM.S otherwise known as the Anglicans/ the Baptists, the Roman Catholics and the Methodists. Others included the Church of Scotland Mission, also known as the United Presbyterians, the Qua Ibo of Northern Ireland, which first established a mission in Eket and Uyo areas in 1887; the Primitive Methodist Missionary Society, which established its first mission post in Calabar and Owerri provinces in 1892 and the Basel Mission, with its first base in the Camerons ${ }^{14}$

It is to be noted that Igboland was a late-comer to Christian missionary enterprise which brought Western education in its wake. The analysis so far depicts the core Igbo area to have witnessed basic missionary work only from 1892 Western educational in-road into the area must however go back to the early 1840's with the arrival of Hoppe Waddell in Calabar. Early educational development in the area must thus be traced from that period.

\section{EDUCATIONAL DEVELOPMENT IN IGBOLAND 1846-1914}

The period from 1846 to 1914 saw intensive missionary activity and expansion in Southern Nigeria, to which Igbo land was a part. During this period, the Church Missionary Society, the (Wesleyan) Methodist Missionary Society, the Roman Catholic Mission, the United Presbyterian Church of Scotland, the Qua Ibo Mission, the Primitive Methodist Missionary Society and the Basel Mission firmly established themselves in this area. As we indicated earlier, the school was a major instrument in the hands of the missions in their proselytization efforts. Apart from introducing basic literary education in reading, writing and arithmetic, the Missions also introduced some vocational training programmes. At Abeokuta, and later at Onitsha, Lokoja and Calabar, agriculture, Carpentry, bricklaying, ginnery were encouraged by the C.M.S, the Church of Scotland Mission and Others. Before we come to this, we need to look more closely on the introduction of basic literary education in Eastern Nigeria, particularly Igboland.

It must be understood that the protestant missionaries-Scottish Presbyterians, Anglicans, Primitive Methodist, Congregationalist or Welsh Baptists, opened schools for two related reasons: to teach their followers to read and to understand the Bible, and to train some of them to become teachers of the others. The Catholic Missionaries on the other hand from the Society of African Missions of Lyons and the Holy Ghost Fathers-sought to first train the Catechists and the core of the teachers who will be involved in teaching the Africans the catechism and basic literacy skills ${ }^{15}$. This literary form of education was welcomed and accepted by Africans, including the Igbo for various reasons. For instance, the people of Bonny wanted this education because they felt that it would make them better traders $^{16}$. But the generality of the Igbo embraced Western education provided by the missions because many parents began to appreciate its economic value. ${ }^{17}$ More fundamentally however, was the fact that the Igbo readily welcomed the Christian faith preached by the missionaries. Because literacy was the means of learning and teaching the Christian religion. The Igbo could not but embrace it. Besides, the means of transmitting the new religion - English Language equally fascinated the Igbo. This is captured by the proceedings of the Church Missionary Society in 1915, which reported that: our religious instruction is tolerated and accepted because it is compulsory and is a means of acquiring English, the language of trade, the law court, and government administration ${ }^{18}$.

This quest for the English Language became more pronounced after the government intervention in the educational needs of the natives, which we will come to shortly. Traditionally however, the protestant missionaries had sought to instruct in the vernacular. They taught English either at the insistence of Africans or to obtain grants from the colonial government. The view of the Church Missionary Society which initially opposed teaching English to the Igbo for religious reasons appeared rather general. The society argued in the early 1900's that:

It is perfectly obvious that education conducted in a foreign tongue amongst utterly illiterate people cannot be productive of any real permanent results... In a few years, the bulk of our coverts.... those who have passed through our schools... would be unable to read the bible in their own language ${ }^{19}$.

There was however a more fundamental reason for this line of thought and predisposition of the missionaries. It must be noted that the CMS was opposed to the kind of education that will fit its followers for anything other than service to the mission.

To this end, the authorities of the mission had directed "that a simple form of secondary education could be provided for aspiring young Igbo Christians..... (but) there was stiff resistance to any 
programe of secondary education that would offer job alternatives to the young Christian men". ${ }^{20}$ Pursuant to this general disposition of the missionaries, one of them cautioned that "the ambition of the Africans to achieve a new social status comparable to that of the Europeans through commercial success was so strong that a whole-hearted patronage of higher education would inevitably sweep away the reason of our residence in the country....our first great work of evangelization". ${ }^{21}$ Before we delve deeper into the intricacies and politics of the introduction of higher and vocational education to the Igbo, we must say a few more words on the rudimentary education provided by the missionaries to the Igbo in the early years.

It is note-worthy that even though the early missionaries began to arrive the Igbo environment in the 1840s, they had covered the Eastern Region with a network of churches and schools even before the British government established colonial rule along the coast in the 1890s; and in the interior, through the eve of the First World War The colonial government left most education to the missionaries and concentrated majorly on concerns regarding the organization of an effective administration and promotion of commerce.

The education the mission provided consisted in the most rudimentary level, of Christian religious studies, geography and arithmetic. Other subjects included grammar, reading, spelling and meaning of words. These were taught with one-overriding aim in mind: to enable the new Christian converts to acquire the mastery of the art of reading and writing, with a view to facilitating the study of sacred writings, and for the performance of religious duties. ${ }^{22}$ This was largely the case until government intervened in the education of its citizen in the 1920s.

\section{ERA Of Government InTERVEntion And Educational DeVelopment In The Igbo ENVIRONMENT.}

Government interest and commitment to the educational needs of the people could be said to have emanated from a vague statement by the British Privy Council's Committee on Education in 1847. The Committee made reference to the need for securing better conditions of life and development of the Africans as a peasant on the land. Pursuant to this, between 1870 and 1876, the colonial Government in Lagos made intermittent attempt to assist some of the missions in their educational endeavours. It ear-marked some funds, ranging from 30 to 300 pounds sterling between 1876 and 1887 as grants to the missions. ${ }^{20}$ This was the situation prior to 1882 , when the first education ordinance was promulgated.

The Ordinance covered the West African territories of Lagos, the Gold Coast, Sierra Leone and Gambia. It must be noted however, that at this time, Lagos was still administered as part of the Gold Coast Colony. The Ordinance made provision for a general board of education, the first ever to be established in West Africa. It had wide ranging powers- to established local boards to advise the general board on conditions for receiving grants - in - aid, teachers' salaries and an Inspector for Schools etc.

In 1886 when Lagos was separated from the Gold Coast Colony, a purely Nigerian educational ordinance was promulgated a year later in 1887. Sequel to this, a Nigerian, Dr. Henry Carr was first appointed Sub-Inspector of schools for the Colony and Protectorate of Lagos. He subsequently became Chief Inspector of Schools for Southern Nigeria between 1915 and 1918.

By the turn of the century, important developments for educational development in the south east of the country occurred. These included the establishment of the Protectorate of Northern Nigeria on 27 December 1899, and the establishment of Southern Nigeria, which now comprised Western, Eastern and Mid-Western Nigeria and the Delta. Having created what came to be referred to as Protectorate of Nigeria by these developments, the government became more involved than ever before in the education of the Eastern people of Nigerian. Besides, as Fafunwa has noted, "it was also at this juncture that the colonial government of Nigeria extended its educational policy to the South-eastern (Igbo) part of Nigeria". ${ }^{24}$ Prior to this period, according to him, and as we have seen, government activities on the educational front were limited to the South-Western part, particularly Lagos.

In 1903, an Education Department was established for the Protectorate of Southern Nigeria, while an educational code, which laid down rules for the provision of primary and secondary education, and decreed that instruction in certain branches of industrial work be given at more advanced schools, was also promulgated in the same year. In 1904, the government established a residential school in Benin, 
and six other primary schools; three for boys and three for girls in the Protectorate of Southern Nigeria. In 1906, following the merger of the Colony of Lagos with the Protectorate of Southern Nigeria to create one administrative unit called Colony and Protectorate of Southern Nigeria, there was the enactment of another education ordinance for the whole area in 1908.

By this time, the number of government schools had climbed to forty six in the Western, eighteen in the Central and sixteen in the Eastern Provinces. Although the schools were under the direct control of the government, they received financial support from the local people in the form of 'subscriptions' or school fees. Provincial boards of education were created for the Western, Central and Eastern Provinces. The first government secondary school, Kings College was founded in Lagos in 1909. But the oldest secondary school, C.M.S Grammar School had also been founded in Lagos in 1859. The disparity in date of founding is instructive as to the currency or otherwise of governmental interest and investment in the education of the people. Besides, the localization of the school also bear witness to the gaps that needed to be closed if Igboland was to catch-up with the advancement already achieved by the Yoruba of Western Nigeria and Lagos.Table1. Below illustrates this:

Table1. Secondary Schools in southern Nigeria between 1859 and 1914

\begin{tabular}{|l|l|l|l|}
\hline Agency & \multicolumn{1}{|c|}{ School } & Location & Founding Date \\
\hline C. M.S & CMS Grammar School & Lagos & 1859 \\
\hline RCM & St. Gregory's College & Lagos & 1876 \\
\hline Methodist & Methodist Boys High School & Lagos & 1878 \\
\hline Baptist & Baptist Boys High School & Lagos & 1879 \\
\hline CSM & Hope Waddell Institute & Calabar & 1895 \\
\hline CMS & Abeokuta Grammar School & Abeokuta & 1908 \\
\hline Government & Kings College & Lagos & 1909 \\
\hline Private African Initiative & Eko Boys High School & Lagos & 1913 \\
\hline CMS & Ibadan Grammar School & Ibadan & 1913 \\
\hline CMS & Ijebu Ode Grammar School & Ijebu Ode & 1913 \\
\hline RCM & St. Mary's Convent & Lagos & 1913 \\
\hline
\end{tabular}

Source: Fafunwa, p. 101

Following government involvement, provincial boards of education were created for the Eastern, Western and Central provinces. These were aimed at effecting central control through local authorities. An Imperial Education Conference held in London on aspects of the educational system of the various colonial territories of the British empire passed certain resolutions, one of which being that each colonial territory needed to prepare annual progress reports on education in its area. This subsequently became a regular feature, and it helped to further galvanize the government unto its responsibilities for the education of its citizens in Southern Nigeria. By the end of 1912, there were 59 government primary schools and 91 mission school aided by the government in Southern Nigeria.

Table2. Indicates schools that were receiving grants-in-aid by the government

\begin{tabular}{|l|l|l|}
\hline Agency & No. of Pri. Sch & No. of pupils \\
\hline (a) C.M.S & 87 & \\
\hline United Free Church of Scotland & 19 & \\
\hline Methodist & 6 & \\
\hline R .C. M & 36 & 11,732 \\
\hline Qua Ibo & 1 & \\
\hline United Native African Church & 2 & \\
\hline (b) Government & 59 & 3,984 \\
\hline (c) Unassisted Schools & & 20,000 \\
\hline (d) Quranic school & & 50,000 \\
\hline
\end{tabular}

Source: S. Phillipson, Grants in Aid of Education in Nigeria, Lagos, 1948 pp.13-14

The government primary schools were established and maintained wholly or in part from public funds. Arrangements were also made whereby local chiefs or native converts accepted responsibility for erecting and maintaining the school buildings and teachers' houses. Assisted mission schools on the hand were given government grants, the deficit being met by school fees and church collections. Schools were required to make the 'Assisted List' by application. During this general period, the following assisted and unassisted schools were in existence. 
Table3. Assisted and Unassisted Schools.

\begin{tabular}{|l|l|l|}
\hline Agency & Name of Institution & Location \\
\hline & Assisted School & \\
\hline Government & King's College & Lagos \\
\hline Anglican (CMS) & CMS Grammar school & Lagos \\
\hline Anglican (CMS) & CMS Girls Seminary & Lagos \\
\hline Catholic & St. Gregory's Grammar School & Lagos \\
\hline Catholic & St. Mary's Convent & Lagos \\
\hline & Unassisted Schools & \\
\hline Anglican (CMS) & Abeokuta Grammar School & Abeokuta \\
\hline Church of Scotland and Mission & Hope Waddell Institute & Calabar \\
\hline Methodist & Boys High School & Lagos \\
\hline Methodist & Girls' High School & Lagos \\
\hline African & Eko Boys High School & Lagos \\
\hline
\end{tabular}

Source: Fafunwa, p.99.

Once again, we note that no mention is made of any school in the Igbo environment either for assisted or unassisted school. The only one located in the Eastern Region: Hope Waddell is conspicuous for its unassisted status. It may be necessary to mention the fact that unlike the C.M.S Grammar School, and others modeled along its curricular, which offered largely literary education, the Hope Waddell Institute presented a singular departure, adding practical courses such as printing, carpentry and mechanics to its literary curricular. This brings us to the issue of vocational and technical education among the Igbo of the early period.

\section{Vocational \& Technical Education Among the Igbo During the Colonial Period.}

The introduction of vocation education in Eastern Nigeria must be credited to the Christian missionaries as part of their evangelization and self - support programme. This started way back in the 1840s. Vocational and technical educations are related in that both of them prepare students for specific occupations. Whereas technical education demands some standard form of formal instruction as a prerequisite, vocational education may or may not. Vocational education may consist largely of practical training or life experience, while technical education involves a body of knowledge organized in a planned sequence of classroom and laboratory or workshop experiences. Furthermore, whereas graduates of vocational programme are generally described as skilled or semi- skilled workers, the graduates of technical programmes include a variety of technicians and engineers ${ }^{25}$

The earliest vocational education took place under the auspices of the Scottish Presbyterian Mission at Calabar; founded in 1846. This was for the purposes of serving the needs of the mission and of providing an alternative to trading for young Efik Christians who were not academically oriented. The missionaries also introduced some crops- Liberian coffee, cocoa, arrowroot, pawpaw, ginger, tomato etc, hoping that their cultivation may support and prepare their pupils to cultivate them commercially in future. The Efik however failed to take advantage of this.

In 1895, the Presbyterians opened the Hope Waddell Institute with industrial, teacher training and secondary departments. Courses were offered to boys in carpentry, masonry, blacksmithing, coopering, and naval engineering; and for girls in domestic science and dressmaking. The church missionary society also opened two important industrial institutions, one for the Ijaw (ijo) at Brass on the western coast of the Eastern Region in 1894, and the other among the Igbo at Onitsha in 1898. The Industrial School at Onitsha taught masonry, brick-making and carpentry. The Pupils were credited with erecting many mission houses and with making furniture on commission from the colonial Government. $^{2}$

The post-war (WW II) era saw the establishment of three different levels of vocational and technical institutions below the college and university. There were handicraft centers to provide pre- vocational training. They were aimed at breaking down the colonial prejudice against working with one's hands in favour of instilling a respect for manual skills and technical achievement. ${ }^{27}$ By 1959, nine handicraft centers in urban centers taught woodworking and metal working to some 7,000 primary school boys. A trade center for the entire Eastern Region to train skilled craftsmen was established at Enugu. Comparable centers existed for the North at Kaduna, and for the West at Yaba. Apprentices were required to complete their primary education before entering the five - year programme. 
Apprenticeship were in building, electrical, mechanical and auto- motive engineering, sheet metalworking, smiting, plumbing and welding. Involving general education course which were equivalent to the secondary level, the Enugu center enrolled some 145 apprentices by 1959.

In 1953, regional branches of the Nigerian College of Arts, Sciences, and Technology opened at Enugu, for the East, at Zaria, for the North, and at Ibadan for the West. The College aimed to train technicians by providing a sub - professional training at an advanced level for civil, mechanical, electrical, and mining engineering, architecture, surveying, accountancy, secretary ship, government, pharmacy, education and fine arts .It also prepared students to sit for the General Certificate of Education (Advanced Level) in arts and science subjects. In the period before independence the college was the only institution of higher education in the entire Eastern Region. ${ }^{28}$

It is to be noted that by 1959 , private industries had started running schools to train their employees. Shell BP Port Harcourt had 87 students, while UATC instructed about 40 students in auto mechanic at Enugu and 68 at Aba. A voluntary agency- the Trade Training Centre at Ahiara, had 160 pupils. Given the level of primary school enrollments in the Eastern Region (grades 1-6) of 1, 430, 514 and secondary at 47, 806, plus 9, 846 in teacher training in 1960, it was evident, according to Victor Nwagbaraocha, that the percentage in primary school going on to any kind of further education secondary, vocational or technical was low. ${ }^{29}$

While it is to be noted that vocational and technical education was introduced into the Eastern Region of Nigeria in the $19^{\text {th }}$ century to serve the needs of the Christian mission and the colonial administration, only secondarily were they designed to provide useful employment to Nigerians, or to develop the country. Besides, such education was never as highly regarded as academic education, as such skilled workers and technicians never possessed as high a prestige, status, and indeed income as lawyers, doctors, teachers, civil servants and businessmen. Due largely to this situation, the Igbo appeared much more attracted to academic education than vocational or technical education. It is to the acquisition of academic education by the Igbo that we now turn.

\section{ERA OF EDUCATIONAL EXPANSION IN IGBOLAND, 1900-1930's.}

The expansion of educational opportunities in the Igbo areas of Eastern Nigeria during this period owed largely to the Roman Catholic Mission. Before the opening years of the $20^{\text {th }}$ century, catholic missionary activities were confined almost exclusively to Onistha. Before this time also, protestant denominations had at least three post primary institutions in Eastern Nigeria: Hope Waddell, Calabar, Methodist College, Uzuakoli and St. Paul's T.T.C. Awka, including numerous primary schools. In fact, before 1900, no serious effort was made to establish schools in the interior of Eastern Nigeria. But with the arrival of Father, (late) Bishop Shanahan in Onitsha in 1902, the situation witnessed a dramatic turn. The move for expansion of missionary work into the interior, east of the Niger had begun under the Norman Priest, Father Leon Lejeune. But as A. Anyandele observed, Father Shanahan "was perhaps the greatest evangelist the Igbo have ever known"30.

Following his dynamic policy of educational expansion in Igboland, and other areas of Eastern Nigeria, schools were opened in such towns as Nri, Nteje, Nsugbe, Isiugwu, Iboro, Oba (Awba), Uli, Ihiala and Okija by 1906. A central boarding school was opened in Ozubulu in 1907, and at Emeku (in Owerri area) in 1912, schools were also opened in several Efik towns and villages, as well as in Ibibioland. ${ }^{31}$ Within the first two decades of the $20^{\text {th }}$ century, there was a phenomenal expansion of primary education in Eastern Nigeria, courtesy of the exertions of Father Shanahan and the Catholic Mission.

It must however be noted that teacher training and secondary schools did not appear to have fared so well until the late 1940s. Apart from the three institutions mentioned earlier, and established by protestant missions, the East was virtually bereft of higher educational facilities beyond the primary level. Between 1928 and 1933 however, the situation began to improve. The former date saw the establishment of St. Charles Teacher Training College at Onitsha, while the latter witnessed the coming on stream of the famous Christ the King College (CKC), also in Onitsha. What was to become a most dynamic phase and robust secondary education system in Igboland appeared to have commenced. With the secondary schools and teacher training colleges as mentioned above, and others that came on steam during that general period; such as St. Augustine's Grammar school, Nkwere, Dennis Memorial Grammar School (DMGS) Onitsha, Aggrey Memorial, Arochukwu, to the 
Government Colleges at Umuahia, Owerri, Afikpo and so forth, the East appeared set not only to compete, but indeed rival the West on the educational front in the period before the outbreak of the Nigerian Civil War in 1967.

The question must be asked as to what was responsible for this quest and desire for Western education among the Igbo. It has been observed that Nigerians' reaction to modern education varied from place to place, and from one ethnic group to the other, particularly in Southern Nigeria. It has also equally been observed that one reason for the desire of the Igbo, especially their Chief(s) to have the presence of the Mission at their communities was probably because of the advantages such presence brought with it- high moral principles, churches, schools, and hospitals. ${ }^{32:}$ As we indicated earlier, another reason was the teaching of English in the schools, especially Catholic schools. As one commentator noted:

Because the Catholic Fathers taught English in their schools instead of the vernacular which the protestants adopted, they were able to attract a large number of young men who were eager to 'learn book': And because English had become the passport for higher positions in the government and business circle, protestants as well as others availed themselves of the English education provided by the Catholic Missionaries ${ }^{33}$

Because of these reasons and others related to them, Chiefs of such Igbo towns as Aguleri, Nsugbe, Oguta, Emekuku, and several other peoples and towns of Igboland, Ibibioland and Efik began to invite the missionaries to their communities ${ }^{34}$. As schools were subsequently established in certain communities, they began to have a domino effect on others. Village schools established by the mission in certain areas were known to have stimulated the desire for education in the next village. As time progressed, there occurred a growing demand for higher education, as communities appealed for secondary schools to be established in their towns. The communities were prepared to make sacrifices in terms of supplying the land, some financial and moral support also, if only their request would be acceded to.

As observed by a commentator "the spirit of cooperation for the improvement of their society was not a new element in the cultural life of the people of the East, especially, the Igbo: He continues: they have from time immemorial, had a tradition of self- help and community effort. This tradition, now galvanized by the peoples thirst for the Christian faith and education, was carefully exploited by the missionaries in their bid for expansion of evangelization and the building of schools. ${ }^{36}$

As a master strategist, Bishop Shanahan recognized and exploited to the full this Igbo people's thirst for education. It may perhaps be necessary to reiterate the role played by some notable chiefs in Igboland in this regard. It is recognized that it was largely due to the friendly reception accorded Father Lutz and his team by the king of Onitsha, Obi Anazonwu and his Council of Elders, and the ready donation of a piece of land for mission purposes that saw to the tremendous progress made by the Catholic mission in the area of implantation of Catholicism and education in Onitsha. ${ }^{37} \mathrm{We}$ also recall the role played by Chief Idigo of Aguleri in the 1890s. Following the invitation he extended to the Catholic Mission, Father Joseph Bubendorf opened a mission in Aguleri in 1890. The exertions of the mission not only saw the conversion of Chief Idigo himself, but by the time he died in 1900, the Catholic faith and education flourished in Aguleri and the surrounding villages.

In the Owerri area, Chief Obiejeshi Ajoku Abuba who brought Father Feral to settle at Emekuku in 1916 became an agency through which Emekuku turned out as a focal point of a vast network of outstations and schools in an extensive area which covered the dioceses of Owerri, Umuahia, PortHarcourt, parts of Orlu and Okigwe. Through the instrumentality and influence of Chief Onyeama of Eke, Fathers Correia and Shanahan succeeded in implanting the Catholic faith and opening schools in Eke, and other towns and villages of present day Enugu Dioceses ${ }^{38}$.

In the same vein, Chief Orjiako of Adazi was instrumental in the planting of Catholicism in Adazi and its surrounding villages and towns that now make up the Awka Diocese. Chiefs of other villages played similar roles in bringing Catholicism and other Christian missions and the complementary formal education to their communities. ${ }^{39}$ Such was the desire and quest for the literary education which the missions provided among the Igbo that by the 1930s and 40s, the Igbo not only closed the gap between her and the Yoruba in terms of acquisition and use of Western education, but indeed surpassed them. As this write has noted elsewhere, "between 1850 and 1930, ( a period of some 
eighty years), the Yoruba appeared to have dominated the acquisition and use of Western education in Nigeria" ${ }^{40}$ So far we have tended to restrict our analysis to primary, secondary and teacher training educational institutions. It may be necessary to highlight university and other tertiary educational strides of the Igbo in the Nigerian environment. This will enable us to gain a wholistic picture of how the Igbo have fared in the acquisition of Western education in Nigeria.

\section{The IGBo \& TerTiARY (UNIVERSITY) EdUCATION IN NigERIA, 1930-1950}

The introduction of higher educational facilities in Nigeria is usually traced to the mid 1920s. A response to the Colonial Office study had led to the "memorandum on Educational Policy in British Tropical Africa", 1925. Consequent upon this memorandum, the British Colonial Government began to give serious consideration to "reorganizing education and expanding opportunities". ${ }^{41}$ Among the recommendations of the memorandum was the establishment of technical and vocational educational schools that may eventually develop to the university level. ${ }^{42}$ This was to provide a higher level of technical training as well as to satisfy the long-expressed desire of Nigerian secondary school graduates for an institution of higher education. In response to this desire, the government opened the Yaba Higher College in 1932.

More specifically, it was the Asquith and Elliott Commissions that actually recommended the establishment of a university college and advanced technical colleges in Nigeria. These were royal commissions on the organization of higher education overseas for all the colonial territories, and for those of British West Africa, respectively. The Commissions published their recommendations in 1945.

The Elliot Commission recommended the establishment of both a University College and an advanced Technical College in Nigeria after the war (ww II). ${ }^{43}$ It is note-worthy that the Asquit and Elliott Commissions gave rise to the establishment of the first university in Nigeria - the University College, Ibadan in $1948 .^{44}$ Four ${ }^{45}$ new universities established in Nigeria in the 1960's also followed the reports of the Ashby Commission and Harbison's High Level Manpower Study for Nigeria. Both reports, like the previous ones, emphasized the role of the university in manpower development in the country.

It must be noted that well before these reports, and the attendant establishment of universities in Nigeria, the Igbo had shown her zeal and enthusiasm for higher educational attainments. The group began to rival, and subsequently overtake the Yoruba in the acquisition of higher education. According to James Coleman, the Igbo drive for rapid educational advance, especially higher education, began in the early 1930's. ${ }^{46}$ Educated Igbo resident in Lagos and other urban centers throughout Nigeria began to organize village, town, and clan improvement and progressive unions. A call was made for the formation of a federation of all small Igbo village and clan unions in Lagos. This marked the beginning of a pan- Igbo movement the main purpose of which was to advance Igbo peoples, principally in field of education. ${ }^{47}$

In the period around the mid 1940s, the Igbo Federal Union, under the leadership of the Lagos Branch, made great strides towards the realization of an Igbo Educational Plan. At one of its mass meeting in Lagos, Dr. Nnamdi Azikiwe is reported to have made a personal donation of 100 pounds sterling to the scheme. ${ }^{48}$ It is equally significant that well before this time, around the 1930s, the Igbo and the Ibidio had began sponsoring students for oversea studies in such diverse fields as law, education and medicine. Dr. Nnamdi Azikiwe is once again credited to have encouraged groups of Igbo students to the United States for university education in $1933 .{ }^{49}$ Having blazed the trail himself to the Americas for university education, when his fore-bears and contemporaries, especially from the Yoruba axis, had settled for the United Kingdom, he was in a vintage position to show such light to his compatriots for American education.

The period 1930 -1950 witnessed intense competition for higher education by diverse groups and individuals, particularly among the Igbo and the Yoruba. This competition may be responsible for the fact that this period appear to have gone down in the annals of Nigerians' quest for higher education as the era of "the golden fleece". As Dan O. Chukwu has indicated, it was also during this period that we had the Greater Tomorrow Scheme of Ozumba Mbadiwe, as well as Nwafor Orizu's educational scheme - the American Council on African Education (ACAE). These schemes were designed to liberalize higher education for bright, but indigent African students in American universities between 1947 and 1952. The scope of what was referred to as horizontal education was widened in 1959 by 
Abyssinia Nwafor Orizu when he established the Nigerian Secondary School, Nnewi, with the motto:" To Educate the Mind is to Liberate it". ${ }^{50}$

The cumulative effect of all these efforts was that whereas between 1850 and 1930, (a period of some eighty years), the Yoruba appeared to have dominated the acquisition and use of Western education in Nigeria, but within the twenty year period of the 1930s and 50's, the table appeared to have turned. Though the Yoruba were the first to send their children abroad, particularly to universities in the United Kingdom, and as we indicated earlier, producing doctors, lawyers, churchmen, teachers, engineers, surveyors, etc to dominate the public services of the period, from the 1930's the situation began to change. This new trend would appear to have been heralded by Dr. Francis Akanu Ibiam, who as the first Igbo Medical Doctor, returned home from Europe in $1935^{.51}$ before this time, in fact, by 1922 , the Yoruba already had eight medical doctors and twenty two lawyers. ${ }^{52}$

But, by 1966, the number of Igbo students at the Universities of Ibadan and that of Lagos - both institutions located in the Yoruba South West of the country was equal to that of the Yoruba. ${ }^{53}$ The trend was not much different in the other universities established in the 1960's as a result of the Ashby Commission's Report, as we had seen. Though no statistics on university enrolment on ethnic basis exist in Nigeria today, it is safe to assert that the Igbo still constitute a sizeable chunk of student population in most Nigerian universities, irrespective of their location. This is more noticeable in federal universities - above 40 in number, as opposed to state and private universities about 44 and 69 in number, respectively. ${ }^{54}$

It is also worthy of note that despite the late arrival of the Igbo on the education turf in Nigeria, they proceeded to produce some of the most prominent personalities in the public service of the 1960's. For instance, Prof. Kenneth Onwuka Dike became the first indigenous Vice-Chancellor of the University of Ibadan, while the appointment of Professor Eni Njoku as Vice Chancellor of University of Lagos, was vehemently opposed by the Yoruba. ${ }^{55}$ Reading ethnic meaning into the appointment, the Yoruba preferred a Senior Lecturer, Dr. Saburi O. Biobaku, as Vice- Chancellor.

Igbo wholesale embrace of Western education also resulted to their dominance of the labour force of the nation. As a commentator put it: the manpower situation in Nigeria ..... was 45 percent Igbo, and threatening to reach $60 \%$, while the North was created (sic) with only 10 percent of the existing posts: For instance, in the railway cooperation (sic) alone by 1964 , out of the 431 senior post (sic) available, the Igbo held $270 \ldots$ and in the Nigeria ports Authority... the Igbo (held) 73 out of 104 posts available. ${ }^{56}$

It is reported that the story was the same in the military. The Igbo dominated the office corps of the army with about $60 \%$ personnel from the ranks of Captain to Colonel. It is equally reported that an Igbo, Chukwuemeka Odumegwu Ojukwu, became the first university graduate to join the Nigerian Army. ${ }^{57}$ Aside from high posts and positions in the civil service and in the military establishment, the embrace of Western education by the Igbo resulted also to their rather ubiquitous presence in almost all urban centers of Nigeria and the Cameroons. It is reported that by the late 1930's, the Igbo were more heavily represented than any other nationality in Nigeria in Yaba Higher College, and in most Nigerian secondary schools, ${ }^{58}$ as we averred earlier. Besides, the number of Igbo appointed to the African Civil Service and as clerks in business firms increased at a faster rate than any other group.

During the forty year period,1911-1951, the number of Igbo in Lagos increased from 264 to 26,000. ${ }^{59}$ There were less than 3,000 Igbo in the Northern Provinces in 1921, but by 1931 the number was nearly 12,000 , and by 1951 , it has increased to more than $120,000 .{ }^{60}$ It is interesting to note that by reason of the acquisition of Western education, most of the Igbo immigrants gravitated to the urban centers where wage employment could be obtained. Consequent upon this, by the end of WWII, Igbo clerks, artisans, traders, and labourers generally, constituted a sizeable minority group in every urban center of Nigeria and the Cameroons, as we indicated earlier. We may as well note that this influx of the Igbo into the towns of the West and North, coupled with their rapid educational development predisposition readily made them competitors for jobs and professional positions. These were perhaps the background to understanding how the compatriots of the Igbo in Nigeria reacted to their rapid acquisition and use of western education, to which we turn presently.

\section{Reaction to Igbo Pursuit of Education by Other Groups}

The rather rapid advancement of the Igbo in the pursuit and acquisition of Western education and its attendant benefits was to draw the envy and hostility of other groups and ethnicities in Nigeria. The 
most prominent of these groups was of course the Yoruba. The obvious reason being that the Yoruba were the group most ardently in competition with the Igbo for opportunities for social mobility in the emerging urban areas, and also on the political turf. On the political front and to a lesser extent also the social arena, the Hausa/Fulani found a soul-mate in the Yoruba in opposition or hatred, even hostility to the Igbo.

Certain instances can be used to illustrate these. For instance, apart from the fact that by 1966, the number of Igbo students at the Universities of Ibadan and Lagos, both in the Yoruba South West, was equal to that of the Igbo as we indicated earlier, ${ }^{61}$ an Igbo, Kenneth Onwuka Dike was appointed the first indigenous Vice-Chancellor of the University of Ibadan. As if that was not enough embarrassment to the Yoruba, another Igbo, Prof. Eni Njoku was also appointed Vice-Chancellor to the University of Lagos. This was vehemently opposed by the Yoruba, who preferred a Senior Lecturer, Dr. S. Biobaku as Vice-Chancellor. According to Okwudiba Nnoli, the conflict over the leadership of Lagos university could be directly attributed to the assertion of ethnic interest by those indigenous to the area of its location. ${ }^{62}$ This trend rather than abetting, has sharpened in contemporary Nigeria.

Another instance can be cited in the events leading up to the outbreak of the hostilities of the Nigerian Civil War following the counter- coup of 1966. It will be recalled that a major impetus to that coup d' etat was the promulgation of Decree No 34, which ostensibly unified the civil service of the federation. As this author has noted elsewhere, four days after the promulgation of this decree, on 28 May 1966, demonstrations against the Aguiyi Ironsi regime broke out across the Northern Region. The placards carried by the demonstrators bore similar messages - "Away with Ironsi", Down with Ibo Domination", "Back to Federalism". It is submitted that this anti-military sentiment quickly turned into anti-Igbo stemming from fears that the Igbo, in some league with the Yoruba intended to isolate the northern Hausa-Fulani, since according to the this thinking, the north had lagged behind the rest of Nigeria in educational attainments. It was believed that a unified civil service will see the better educated and assertive Igbo take over whatever position that was available even in the Northern Region. Thus the sentiment of Igbo domination of the country voiced during the nationalist era began to stoke more and more violent demonstrations and protest against the Igbo, until it culminated in the civil war, 1967-1970. ${ }^{63}$

This was essentially a reaction to Igbo advancement in the acquisition of Western education. As indicated, the enthusiasm and determination with which the Igbo embraced Western education, coupled with the assertive nature of group saw them not only flocking to secondary schools in the then Western Region, but also thenceforth being appointed to the African Civil Service and as clerks in businesses at a faster rate than any other Nigerian group. Besides, their influx into the towns and urban centers of the West ostensibly at the behest of their rapid educational development credentials, made them competitors for jobs and professional positions across the nation.

There is yet another instance of the reaction of their compatriots to the educational attainments of the Igbo. This time it appeared to wear the garb of a policy. It is common knowledge that Federal Civil Service examination for recruitment of personnel into the service in 1965 was subsequently cancelled because it was alleged that graduates of the newly established University of Nigeria at Nsukka (UNN) (most of whom were of course Igbo), occupied the first twenty positions before graduates of other Nigerian universities at the time. ${ }^{64}$

It may be necessary perhaps to indicate that the so-called influx of the Igbo into schools in the North and West may have continued despite the negative reactions of their compatriots. We may use the tertiary level (universities) to illustrate, and in the period 1985/1986.

Table4: Percentage Distribution of Students by Geopolitical Regions, 1985/86.

\begin{tabular}{|l|l|l|l|l|l|l|}
\hline Institutions & State of Location & West & East & North & Others & Total \\
\hline $\begin{array}{l}\text { Federal Universities } \\
\text { WEST }\end{array}$ & & & & & & \\
\hline OAU Fmrly Unife & 42 & 48 & 7 & 2 & 1 & 100 \\
\hline University of Ibadan & 31 & 36 & 14 & 7 & 2 & 100 \\
\hline University of Lagos & 14 & 63 & 18 & 4 & 1 & 100 \\
\hline University of Benin & 58 & 14 & 25 & 2 & 1 & 100 \\
\hline Average & 36 & 43 & 16 & 4 & 1 & 100 \\
\hline
\end{tabular}




\begin{tabular}{|l|l|l|l|l|l|l|}
\hline EAST & & & & & \\
\hline University of Nig. Nsukka & 52 & 9 & 36 & 1 & 2 & 100 \\
\hline University of Calabar & 56 & 8 & 34 & 1 & 1 & 100 \\
\hline University of P. Harcourt & 41 & 14 & 44 & 1 & & 100 \\
\hline Average & 50 & 10 & 38 & 1 & 1 & 100 \\
\hline NORTH & & & & & \\
\hline ABU Zaria & 20 & 6 & 65 & 1 & 8 & 100 \\
\hline University of Jos & 20 & 25 & 38 & & 17 & 100 \\
\hline University of Sokoto & 43 & 4 & 45 & 2 & 6 & 100 \\
\hline University of Maiduguri & 32 & 12 & 46 & 1 & 9 & 100 \\
\hline Bayero Kano & 41 & 1 & 56 & - & 2 & \\
\hline University of Ilorin & 40 & 6 & 2 & 1 & 51 & 100 \\
\hline Average & 32 & 9 & 42 & 1 & 16 & 100 \\
\hline State Universities West & & & & & & 100 \\
\hline Ogun State University & 87 & 12 & 1 & - & - & 100 \\
\hline Ondo State University & 90 & 8 & 2 & - & - & 100 \\
\hline Lagos State University & 59 & 34 & 7 & - & - & 100 \\
\hline Bendel State University & 67 & 7 & 16 & 3 & 7 & 100 \\
\hline EAST & & & & & & 100 \\
\hline Imo State University & 65 & 17 & 18 & - & - & 100 \\
\hline Anambra State. University & 82 & 3 & 15 & - & - & \\
\hline Rivers State University & 73 & 4 & 14 & - & 9 & - \\
\hline Cross River State University. & 93 & 2 & 5 & - & - & 100 \\
\hline
\end{tabular}

Source: Computed from NUC: Annual Reports 1985-86, in Philip A Akpan, "Role of Higher Education in National Integration", P.300.

From this table we see that while the East has an average attendance of universities outside their region of West and North of $16 \%$ and 9\%, respectively, the West has an average of $10 \%$ and $1 \%$ attendance of universities in the East and North, respectively. There is no reason to indicate that the trend may have changed in the contemporary times. The Igbo is seen to be resilient in her quest for education in spite of whatever may be the reaction of their compatriots.

\section{CONCLUDING REMARKS}

In Nigeria, the Federal Government is the sole authority vested with powers to determine policy objectives for the universities, and to set up agencies for implementing measures for achieving them. The implementing agencies are the National Universities Commission (NUC), the universities themselves and the Joint Admissions and Matriculation Board (JAMB).

Set up in 1962, to coordinate university development in Nigeria, the NUC was unable to perform this role properly prior to $1975 .{ }^{65}$ This was because before this time, higher education was a joint responsibility of both State and Federal government. By 1975, however, higher education became an exclusive responsibility of the Federal Government and the NUC assumed greater role in the administration of universities. In spite of the reversal of higher education in 1979 as joint responsibility, the NUC was still charged with enforcing Federal Government policy measures in universities, which include allocating financial support and ensuring uniform standards.

In 1977, the Joint Admissions and Matriculation Board (JAMB) was established. This was on the recommendation of the Committee of Vice - Chancellors of Nigerian Universities. Its main function was to stream line university admissions and entrance so as to eliminate the problem of multiple admissions. The body was also conceived to ensure that each university was a microcosm of the country in terms of admission and ethnic composition. ${ }^{66}$

In general terms, the objectives of university education are seen to be dynamic, and they tend to reflect the economic and social priorities of the country. The earliest specifications of these objectives appear to have been made by the Asquith and Elliot Commissions on higher education. Apart from the overriding necessity for manpower development, the Asquith Commission reported that the raison d' etre for university education was:

To produce graduates with leadership qualities which self- rule required. To produce professional men and woman to take over senior appointment in health and administration and other services from 
expatriates. To serve as a platform for producing true nationalists... who would form political institutions with national character. To refine and maintain the best in our local traditions and cultures and yet be capable of holding their own intellectually on the international scene ${ }^{67}$

It is necessary to note that the Asquith and Elliot Commissions preceded the establishment of the first University in Nigeria, - the University College, Ibadan, in 1948. Yet it was in the universities established pursuant to the objectives of the Commissions that the Igbo received the treatment itemized above in the hands of their compatriots. It is further seen that after the second decade of independence, issues of social justice, equity, national unity and national integration began to come into some prominence in the educational policies of the country. For instance, the first stated objectives of the educational programme of the Third National Development Plan, 1975-80 was; "to expand facilities for education aimed at equalizing individual access to education throughout the country. ${ }^{68}$ The Implementing Committee for the National Policy on Education (1978-79) stated the new role for universities as "serving as instruments for fostering national unity"

It does appear as if these measures indicated so far - ranging from reports of the commission set up to advice on university education, to other governmental agencies such as the NUC, JAMB, the Development Plans etc - were all in response to Igbo predicament and bewilderment in their quest for the acquisition and use of Western education in Nigeria. If that was to be case, the situation would have been radically different today from what it is. The reality however, is that as it was in the 60s, so it is today. Nnoli's argument that the conflict over the headship of Lagos University in 1965 could be directly attributed to the assertion of ethnic interest by those indigenous to the area of its location holds true today, as it did then.

The general trend since then, according to him, (and we cannot agree more with him), has been that only an indigenous head of a university can expect to have a crisis - free tenure of office. ${ }^{69}$ It is indeed common practice for the indigenous people of a state or locality where a university, or other educational institution is located to regard it as their own institution. It is within this premise that the allegation that the attempted secession of Eastern Nigeria from the rest of the country in 1967 was fuelled by Igbo students and staff at the University of Nigeria, Nsuka, is believed.

It is submitted that if Nigeria must make progress generally, and achieve her educational policies, deliberate efforts must be made to jettison the parochialism of ethnic jingoists.

\section{REFERENCES}

[1] The New International Webster's Comprehensive Dictionary of the English Language, Naples, Florida, Typhoon Int.1, 2004, P. 401.

[2] Emmanuel J. Ibout, "Education, Values and Leadership Crisis in Africa", in, Ikoro, Journal of Institute of African Studies, UNN, Vol. 10, Nos 1\&2, 2014, p. 233.

[3] P.E. Nmah \& K.L. Nwadialor, "Mission Education and Civilization in Nigeria, 1842-1960: An Ethical Reflection", in Dan O. Chukwu \& Eugene I. Nnadi (eds) Readings in the Humanities and Education, Enugu, His Glory Publication, 2011, P. 267, quoted in A. B. Fafunwa, History of Education in Nigeria, London, Allen and Unwin, 1974, P.17.

[4] Sylvanus I. Okoro, "The Igbo and Western Education in Nigeria, 1900- 2010", in Dan. O. Chukwu, Sylvanus I. Okoro, Egodi Uchendu \& Justin G. Nkem - Onyekpe (eds), Studies in Igbo History, Enugu, Nnolix Publ, 2016, P. 549.

[5] See Victor I. Nwagbaraocha, "Vocational and Technical Education in Eastern Nigeria During the Colonial Period", Proceedings of the Meeting of the French Colonial Historical Society, Vol. 8, Michigan , Michigan University Press, 1985, P. 125, also in http://www.jstor.or/stable/42952136, Accessed 24/01/17.

[6] Victor I. Nwagbaraocha, Ibid.

[7] See James S. Coleman, Nigeria: Background to Nationalism, Berkeley, Univ.of California Press, 1958, P. 15. It is to be noted that Southern British Cameroons was administered as part of Southern Nigeria during the Mandate period, and as part of the Eastern Region during the Trusteeship period.

[8] A. Babs Fafunwa, History of Education in Nigeria, Ibadan, NPS Educational Publ., 1974, P. 70

[9] Fafunwa, PP. $71-79$

[10] Perhaps, it may be necessary to indicate that the word 'Lagos' was derived from the Portuguese word Lago or Lagoon; the Island of Lagos being named after a similar port in Portugal called 'Port Lagos', See Fafunwa, p.72. 
[11] Fafunwa, p. 75

[12] T.F. Buxton, The African Slave Trade and its Remedy, London, 1840, in Fafunwa, P. 76.

[13] F. Deanville, A Hundred Years in Nigeria, Longman, Curgate Press, 1942.

[14] See Fafunwa, PP. 76 - 79

[15] See Victor I. Nwagbaraocha, "Vocational and Techinical Education in Eastern Nigeria during the Colonial Period", PP 126- 27.

[16] Kalu E. Ume, The Rise of British Colonialism in Southern Nigeira, 1700-1900, Smithtown, Exposition Press, 1980, P. 166.

[17] Oliver Ifeanyi, Anyabolu, Nigeria: Past to the Present, Enugu, Classic Public, 2000, P. 65

[18] J.C. Anene, "CMS Proceedings of 1915", in Southern Nigeria in Transition, Cambridge, 1966. P. 326.

[19] Felix Ekechi, Missionary Enterprise and Rivalry in Igboland, 1857 - 1914, London, Frank Cass, 1972, P. 191.

[20] Ekechi, P. 185

[21] Ekechi, P. 191

[22] Fafunwa, P. 71

[23] See Fafunwa, pp 93-94, for details.

[24] Fafunwa P. 96.

[25] Nwagbaraocha, P. 125.

[26] Annual Report of the Education Department, Southern Nigeria, 1926, pp. 7-9

[27] Michael Goldway, "Report on the Investigation of Vocational Education in Eastern Nigeria", Ministry of Education, E. Nigeria, O. D. No. 13 of 1962, Enugu, 1962, p. 7, see also "Memorandum on Educational Policy in Nigeria", Session Paper No. 20 of 1947, p. 20; in P. Kilby, Technical Education in Nigeria, Oxford Unv. Institute of Economics \& Statistics Bulletin, May 1964, pp. 1854; in Nwagbaraocha, P. 133.

[28] See Otonti Nduka, Western Education and the Nigerian Cultural Background, Ibadan, OUP, 1965, P. 60

[29] Nwagbaraocha, P. 134.

[30] E. A. Ayandele, Missionary Impact on Modern Nigeria, 1942-1914, New York, Longman, 1960. P. 265.

[31] See K.B.C Onwubiko, "The Catholic Church and the Development of Education in Eastern Nigeria (18851984)", in Rev. Fr. Dr. Celestine Obi (ed), A Hundred Years of Catholic Church in Eastern Nigeria (1885-1985), Onitsha, Africana Fep Publi; 1985, P. 232.

[32] Ekechi, P. 91.

[33] Ekechi, PP 102-103

[34] See Onwubiko, in Obi (ed) p. 236.

[35] Onwubiko, p. 250

[36] E. Isichei, The Ibo People and the Europeans, London, Faber and Faber, 1973, p. 173.

[37] D. B. Abernethy, The Political Dilemma of Popular Education, California, Stanford Univ. Press, 1969, P56.

[38] Paul Inyang, "Some Mission Schools in Eastern Nigeria Prior to Independence", in Brian Holmes (ed), Educational Policy and the Mission Schools, London, Routledge and Kegan Paul, 1967, P. 306.

[39] For much of these efforts, see Onwubiko, pp 248-250.

[40] Okoro, "The Igbo and Western Education in Nigeria 1900-2010”, in Dan. O. Chukwu, Sylvanus I. Okoro, Ejodi Uchendu \&Justin G. Nkem Onyekpe (eds), P. 560.

[41] Nwagbaraocha, P. 130.

[42] See Advisory Committee on Native Education in British Tropical Dependences, Education Policy in British Tropical Africa (CMO. 2347, London, HMSO, 1925) in Nwagbaraocha, P. 130.

[43] See L John Levis Phelphs, Stokes Report on African Education, London, Oxford Univ. Press, 1962, pp 5 $-9$.

[44] Philip A. Akpan, "The Role of Higher Education in National Integration in Nigeria”, Higher Education, Vol. 19. No 3, 1990, P. 296, also in URL: http://www.jstor.org/stable/3447273, accessed Tue, 24 Jan.2017.

[45] Instead of four new universities recommended by the Ashby, Commission, the government established five universities, at Nsukka, Ibadan, Ife, Lagos and Zaria. See Fafunwa, P. 167.

[46] See Coleman, Nigeria: Background to Nationalism, P. 339

International Journal of History and Cultural Studies (IJHCS) 
[47] Coleman, P. 340

[48] Coleman, P. 341

[49] See Fafunwa, P. 150

[50] The Philosophy and concept of Horizontal educational scheme was a departure from the Britishperpendicular education which was essentially literary and theoretical as opposed to the American multilateral and comprehensive education as espoused by Nwafor Orizu. See Dan. O. Chukwu, "Abyssinia Nwafor Orizu and the Philosophy of African Irredentism" in G.O. Ozumba (ed), AColloquim of African Philosophy II, Calabar, Jochrisam Publ., 2004, for details of this philosophy.

[51] Fafunwa, P. 340

[52] See E.N. Ota "Shifting Sands: Igbo Ethnicity in Nigeria Since 1936", in Dan. O. Chukwu, Sylvanus I. Okoro Egodi Uchendu \& Justin G. Nkem-Okyekpe (eds), P. 523.

[53] Ota, quoted in Okwudiba Nnoli, Ethnic Politics in Nigeria, Enugu Fourth Dimension Publ; 1980, p. 219

[54] See National Universities Commission portal on http://nuc.edu.ng.Accessed2/22/2017. http://nuc.edu.ng/nigerian-universities/ federal universities/ state universities/private universities/

[55] Ota, in Dan Chukwu et al, P. 523

[56] Ota, in Ihediwa Nkemjika Chime, "Unequal Peace: A Critique of the Post-War Reconciliation", in U.O. Anyanwu and U.U. Okonkwo (eds), Perspectives on the Nigeria Civil War, Owerri, IMSU Press, 2010, p. 37.

[57] See Alexander Madiebo, The Nigerian Revolution and the Biafra War, Enugu, Fourth Dimension, 1980, P. 4.

[58] Coleman, P. 333

[59] See P. Amaury Talbot, The Peoples of Southern Nigeria, Oxford, 1926, vol iv; Population Census of the Western Region of Nigeria, 1952, bulletine no 5, Lagos, 1953, in Coleman, P. 332.

[60] Coleman, P. 332

[61] See Nnoli, Ethnic Politics in Nigeria, P. 219.

[62] Nnoli, "Education and Ethnic Politics in Nigeria", African Development, 1, 3, 37, - 53; in Philip. A. Akpan, "The Role of Higher Education in National Integration", in Higher Education, vol 19 No 3, 1990, pp. 299-305.

[63] S. I. Okoro and P. U Omejie "Ethnic Nationalism in the Nigerian Army: Lessons, Legacies and Progonisis of the First Military Coup d' etat, 1966-2015", in International Journal of Research, vol. 03, Issue 18, Dec. 2016. Available online. Https://edupediapublications.Org/ journals/index. Php/IJR/pp.471-494.

[64] See Okoro, "The Igbo and Western Education in Nigeria; Dan O. Chukwu, et al, (eds), p. 561.

[65] See A. A. Ali; "Varsities as Agents of National integration", in National Concord, July 5, P3, July 6, P. 3,1988 .

[66] Ali, 1988

[67] Ali, Ibid.

[68] Federal Republic of Nigeria, "Third National Development Plan", 1975-80, vol.1. Lagos, Ministry of Economic Development; 1975.

[69] Nnoli, "Education and Ethnic Politics", in Philip A Akpan, 1990, PP, 293-305.

\section{AUTHORS' BIOGRAPHY}

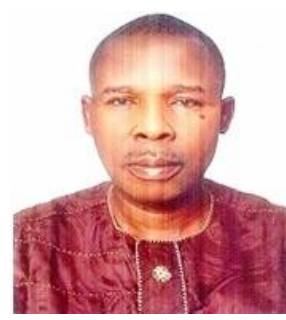

Dr.S.I.Okoro is Senior Lecturer in History and International Relations in Ebonyi State University, Abakaliki, Nigeria. He specializes in International Relations, Security Studies and Studies of Plural Societies. His publications, which straddle these and related areas have appeared in diverse local and international on-line and ranked learned outlets. He is the author of Ethnic Nationalism in Rwanda and the African Great Lakes Region, on http://dnb.d-nb.de amongst other single authors and edited works.

Citation: S.I. Okoro, The Igbo and Educational Development in Nigeria, 1846 -2015. International Journal of History and Cultural Studies (IJHCS). vol 4, no. 1, 2018, pp. 65-80. doi:DOI: http://dx.doi.org/ 10.20431/2454-7654.0401005.

Copyright: (C) 2018 Authors. This is an open-access article distributed under the terms of the Creative Commons Attribution License, which permits unrestricted use, distribution, and reproduction in any medium, provided the original author and source are credited. 